AGRARIS: Journal of Agribusiness and Rural Develpoment Research

Vol. 4 No. 2 Juli-Desember 2018
Joko Mariyono ${ }^{1 *}$, Hanik A. Dewi ${ }^{2}$, Putu B. Daroini ${ }^{2}$, Evy Latifah², Abu

Z. Zakariya ${ }^{2}$, Arief L. Hakim ${ }^{3}$, Victor Afari-Sefa ${ }^{4}$

1) Program Studi Magister Manajemen, Program Pascasarjana, Universitas

Pancasakti, Tegal

2) Balai Pengkajian Teknologi Pertanian Jawa Timur

3) Universitas Islam Raden Rahmat, Malang, Jawa Timur

4) World Vegetable Center, West and Central Africa Regions, Mali

*) corespondence e-mail: mrjoko28@gmail.com

\section{Farming Practices of Vegetables: A Comparative Study in Four Regions of East Java and Bali Provinces}

DOI: http://dx.doi.org/10.18196/agr.4263
Results of analysis were presented in graphical and tabular forms. Farmers mostly selected hybrid varieties of vegetables because of economic reasons, such as high yield, good appearance and high number of fruits. Anthracnose and late blight were perceived as the most important disease in chilli and tomato respectively. Farmers controlled pests and diseases using pesticides. In general, farmers perceived that irrigation was one of limiting factors of vegetable farming. Poor drainage was one of the crucial issues in Bali. Farmers mostly sold vegetable once harvested. Post-harvest handling was still traditional, where farmers still less pay attention on post-harvest, even though they observed the economic advantage of post-harvest. Based on the existing practices, a special extension on vegetable production needs to be formulated appropriately, based on the specific characteristics of each region.

Keywords: agronomic and ecological aspects; farmer's perception; vegetable farming

\section{INTRODUCTION}

Along with population growth, Indonesia is coping with food and nutrition security concerning household hunger and malnutrition. The production of vegetable crops in Indonesia has grown both for domestic consumption and in exports to some extents. Diversification into vegetables could benefit many rural people by increasing both production and employment. Diversification into vegetables could thus play a significant role in supporting food and nutrition security in Indonesia (Weinberger \& Lumpkin, 2007).

Vegetables are high-value cash crops; their production could well be targeted for inter-island and export marketing. As a major source of nutrients in the diet, providing a broad spectrum of essential micronutrients including pro-vitamin A, iron, and zinc (Latifah, Andri, \& Mariyono, 2014), vegetables can contribute to the prevention of malnutrition disorders (Kuntariningsih, 2018). While global types of vegetables (such as tomato and onion) are often more popular, there is a need to rise the utilisation of indigenous vegetables' enormous potential for daily sustenance, to diversify production systems and diets with indigenous vegetables, and to expand their use as cash crops. There is a potential to explore the vegetable production in a local economy (Widodo, 2015; Istiyanti, Khasanah, \& Anjarwati, 2015). 
Indonesian vegetable production grew by an average of $8 \%$ per annum, from 6.9 million tons in 2001 to more than 9 million tons in 2005, to cover almost one million hectares with an average productivity of 9.6 tons per hectare. Chilli production accounts for $20 \%$ of the land currently used for vegetable production but produces only $12 \%$ of the total vegetable production due to low average yields. In comparison, cabbage and potato use only $6.3 \%$ and $6.8 \%$ respectively of vegetable land and have much higher yields, resulting in significant production volumes. The major vegetables cultivated in Indonesia (besides mushrooms) and their average yields are cabbages $(22.4 \mathrm{t} / \mathrm{ha})$, chilli $(4.7$ to $6.4 \mathrm{t} / \mathrm{ha})$, potato (16.4 t/ha), shallot and onions ( $8.8 \mathrm{t} / \mathrm{ha})$, and tomato (12.6 t/ha) (White et al., 2007).

The production of vegetables increased during the last decade (Figure 1). Chilli had the highest growth rate. Production of chilli increased from 1.2 million tons in 2003 to almost 1.9 million tons in 2013. This is due primarily to substantial improvements in irrigation infrastructure and the use of better cultivars over the period. Other vegetables also increased steadily because of the same factors noted for chilli. Among the vegetables grown in Indonesia, chilli is the highest in terms of acreage and volume of production.

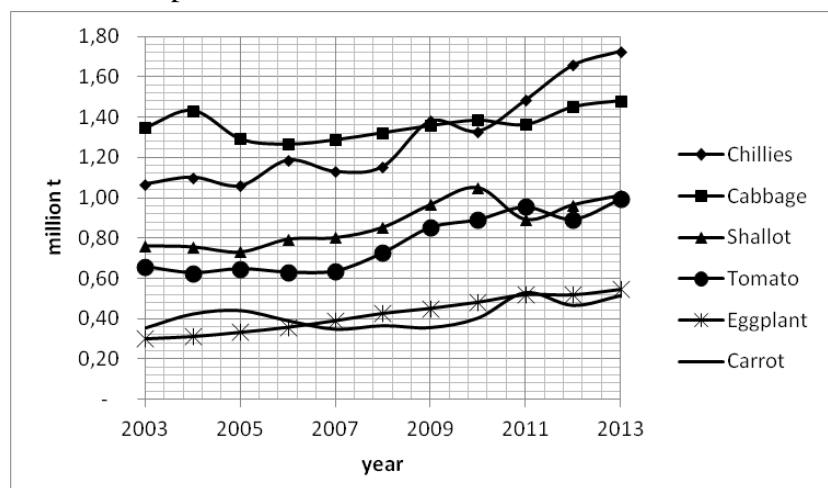

Source: (BPS, 2014)

\section{FIGURE 1. THE DYNAMIC TREND OF VEGETABLE PRODUCTION IN INDONESIA, 2003-2013}

Improvements in agronomic practices of vegetable production help farmers increase production. For example, seed technology can lead to use of other technology (Bhattarai \& Mariyono, 2016). This is because vegetable production depends on conditions of the agroecosystem. Agroecosystem conducive for vegetables leads to potential production. Many factors are affecting vegetable production, starting from seed selection, land preparation, crop maintenance, crop protection, harvest and postharvest handling (Istiyanti et al., 2015). Before interventions for improving agronomic practices in vegetable production, we need to understand the current practices of vegetable production. As agroecosystem in Indonesia varies across regions, it is essential to see the regional variation of agroecosystem that makes farmers cope with local problem wisely The specific local problem needs a different approach, and this is useful for appropriate project intervention. This study aims to provide current farmers' practices of vegetable production, particularly for chilli and tomato, in main four vegetable-producing areas in East Java and Bali provinces. The results are expected to be used by policymakers in formulating appropriate intervention programs.

\section{METHODS}

This study used a survey and adopted a framework of integration of qualitative and quantitative survey to meet the above objectives. The qualitative survey approach used for the collection of social and institutional issues involved in chilli farming and the information at the community or group level average in the village. Quantitative one used the individual interview. This was conducted by interviewing selected farmers. Interviews were conducted by enumerators using structured questionnaires. Each selected farmer was questioned individually to avoid farmers from being influenced by one another. Every response from farmers was recorded in a questionnaire. Each questionnaire only recorded one farmer.

This survey illustrated agronomic production issues involved in vegetable cultivation in East Java and Bali provinces of Indonesia. East Java was selected because this province is the second largest vegetable 
production in Indonesia, but the productivity was lower than that in other provinces (BPS, 2016). Bali was selected because there was a unique farming system in the regions, particularly the cultural and business environment that differ from other provinces of Indonesia (BPS, 2015). The assessment was based on farmers' survey carried out during the research period of 2013-2014 in four communities: Kediri and Blitar of East Java; and Bangli and Tabanan of Bali. Data for this study were compiled from a quantitative survey of 360 farm households located in four major vegetable producing regions. Each of the communities/districts selected was the centre of vegetable production, particularly chilli, tomato, eggplant, shallot and cabbage/lettuce. However, tomato and chilli are the leading vegetable crops grown by surveyed farmers, thus this paper mainly discussed both commodities. Other crops such as eggplant, shallot, cabbage only minors, and usually grown as intercrops along the site of the land border; and thus, such crops were not discussed. Each site represents a distinct variation of production characteristic and agro-ecology settings of vegetable farming practice in the region.

Three major forms of descriptive data were analysed: sample means, frequency and proportion, and weighted rank order. Analyses on frequency were carried out by counting the number of farmers who responded to a certain category of response/issue in the questionnaire. Once the data were obtained, the percentage of those from the sub-total of each district and total samples in the project area were calculated. If the frequency of a certain variable is higher than the others, then this particular variable is considered more important. Mean (average) value of a particular variable was estimated by calculating the sample average of the variable.

The report uses descriptive analysis. Mean comparison of quantitative data among regions was tested using simple t-test. For non-quantitative data, the analysis focused on the frequency of farmers' response. Qualitative data are represented by proportion (percentage) of farmers providing response relative to total farmers in each region and overall. The common formula of proportion is expressed as:

$$
Y=\frac{n}{N} * 100 \%
$$

where $\mathrm{n}$ is the number of farmers providing response, $\mathrm{N}$ is total number of sampled farmers. Further analysis of the importance of information was conducted using a weighted average. Graphs were used to help in comparing important selected information visually.

The mean value was calculated using the formula:

$$
\bar{X}=\frac{\sum_{i=1}^{N} X_{i}}{N}
$$

where $\mathrm{Xi}$ is the variable of ith to be analysed, $\mathrm{N}$ is the number of sampled farmers. To provide information on the significance, a statistical t-test was provided as reported by the SPSS software package, which is formulated as:

$$
t_{\text {test }}=\frac{X_{i j}-X_{i k}}{S D_{j k}}, \text { for } k \neq j
$$

where subscript $\mathrm{k}$ and $\mathrm{j}$ refer to the different districts, and SDjk is the standard deviation obtained from $\mathrm{xj}$ and $\mathrm{xk}$. In this case, if the value of $\mathrm{t}$-test is greater than the value t-table at $90 \%$ confidence interval, then the average of the particular variables is significantly different from other survey sites.

For particular important factors, analyses on weighted rank were conducted by calculating the score reported by farmers. The weighted average rank is formulated as

$$
\bar{R}=\frac{\sum n * S}{N}
$$

where $\mathrm{n}$ is the number of farmers responding to each category, $\mathrm{S}$ is the score, and $\mathrm{N}$ is the total number of samples. A higher score was focused on a particular variables (responses) when farmers reported that such a variable was more important. For example, during the field survey, if there are five choices, and a farmer gave the first rank for a specified variable in a list, then the particular variable is scored (ranked) as one. If the farmer located it in the second rank, then it is scored two, and so on. If the farmer mention nothing, then the score for this particular factor is considered zero. Thus, the higher the value of weighted average rank, the more important the factor (response) mentioned by many farmers during the survey. The statistical analysis was run by using the software package of SPSS $\AA$ and MSExcel ${ }^{\circledR}$.

\section{RESULTS AND DISCUSSION}




\section{VARIETY SELECTION}

Farmers cultivated small, curly and big chillies, and leafy vegetables and fruit tomatoes. Almost all varieties of chilli and tomato were identified hybrids. Farmers got the varieties from agricultural input stores around their villages. Small chilli was mostly grown in Kediri, and the popular variety was Bhaskara; curly chilli was mostly grown in Blitar, and the popular variety was TM999. While big chilli was also grown in Blitar, and the popular variety was Gada-MK. In Bali, farmers cultivate hot chilli, and the most popular variety was Wibawa. For tomato, Timothy was the popular variety in East Java. While in Bali, Martha and Menara were the hybrid variety of tomato that was mostly grown by farmers. The variation in types and varieties of chilli and tomato in each location was to fulfil market demand and consumer preferences (Mariyono et al., 2018). Colour, shape, aroma and size were characteristics of tomato and chilli. The characteristics of chilli became more matter when the supply of both commodities was high. Different characteristics during peak season led to a low price. Other factors such as agro-climate condition, pests and diseases also affected the selection of types and varieties.

Farmers selected such variety because of various reasons. Almost all farmers in all regions stated that economic reasons, such as high yield, good appearance and a high number of fruits behind the variety selection. It is common that economic motives are behind the choice of varieties. Resistance to pests and diseases was also a strong motive for farmers to select varieties (Mariyono et al., 2010). The seed becomes one of the important factors affecting the productivity of vegetables (Sita \& Hadi, 2016).

\section{PESTS AND DISEASES}

Pests and diseases are major limiting factors (Paramanandham et al., 2017). Farmers need to cope with pests and diseases to get the potential of production. Table 1 shows the most important pests and diseases in tomato and chilli. Anthracnose was perceived as the most important disease in chilli, which potentially causes yield loss of up to around
$27 \%$. In Bali, potential yield loss caused by the disease was higher than that in East Java.

TABLE 1. TOP THREE OF PESTS AND DISEASES IN CHILLI AND TOMATO

\begin{tabular}{llrrrrr}
\hline \multirow{2}{*}{ Crop } & Pests and & \multicolumn{5}{c}{ Percentage of loss (\%) } \\
\cline { 2 - 7 } & diseases & Tabanan & Bangli & Blitar & Kediri & Total \\
\hline \multirow{2}{*}{ Chilli } & Anthracnose & $51_{\mathrm{a}}$ & $38_{\mathrm{a}, \mathrm{b}}$ & $25_{\mathrm{b}}$ & $20_{\mathrm{b}, \mathrm{c}}$ & 27 \\
& Fruit fly & $300_{\mathrm{a}, \mathrm{b}}$ & $71_{\mathrm{a}}$ & $25_{\mathrm{b}}$ & $22_{\mathrm{b}, \mathrm{c}}$ & 32 \\
& Aphids & $10_{\mathrm{b}}$ & $18_{\mathrm{a}}$ & $13_{\mathrm{a}}$ & $23_{\mathrm{a}}$ & 18 \\
& Late blight & $7.94_{\mathrm{a}}$ & $5.00_{\mathrm{a}, \mathrm{b}}$ & $0.22_{\mathrm{b}}$ & $2.80_{\mathrm{a}, \mathrm{b}}$ & 3.97 \\
\multirow{2}{*}{ Tomato } & Phytophthora & $8.97_{\mathrm{a}}$ & $0.23_{\mathrm{b}}$ & $0.02_{\mathrm{b}}$ & $3.21_{\mathrm{a}, \mathrm{b}}$ & 3.39 \\
& Fruit borer & $4.21_{\mathrm{a}}$ & $0.68_{\mathrm{a}}$ & $0.00_{\mathrm{a}}$ & $1.97_{\mathrm{a}}$ & 1.82 \\
\hline
\end{tabular}

Note: Numbers in the same row and sub-table not sharing the same subscript denote significantly different evaluated at $p<.05$ in the twosided test of equality for column means. Cells without subscript are not included in the test. Tests assume equal variances.

For tomato, late blight and Phytophthora were perceived the most important, despite low potential of yield loss. The rate of yield loss of tomato caused by pests and diseases were perceived low. This is an indication that farmers were able to control. But, if such pests and diseases were not controlled, the rate of yield loss could be very high, even could reach up to $100 \%$, during bad weather.

\section{TABLE 2. THE RESULTS OF THE CONTROL MEASURE OF PESTS AND DISEASES}

\begin{tabular}{llrrrr}
\hline \multirow{2}{*}{ Crop } & \multirow{2}{*}{ Results } & \multicolumn{4}{c}{ \% farmers' statement } \\
\cline { 3 - 6 } & & Tabanan & Bangli & Blitar & Kediri \\
\hline \multirow{4}{*}{ Chilli } & Effective & 12.36 & 10.11 & 28.09 & 49.44 \\
& Partly effective & 6.45 & 17.20 & 38.71 & 37.63 \\
& Not effective & 2.56 & 25.64 & 38.46 & 33.33 \\
\hline \multirow{4}{*}{ Tomato } & Effective & 65.22 & 2.17 & 4.35 & 28.26 \\
& Partly effective & 19.23 & 15.38 & 7.69 & 57.69 \\
& Not effective & 50.00 & 50.00 & 0.00 & 0.00 \\
\hline
\end{tabular}

In all areas, farmers made efforts to reduce the yield loss by controlling pests and diseases. Farmers did not carry out a single method, but they apply a combination of control measures to reduce the attacks of pests and diseases. Farmers always applied pesticides with the frequency of spray 2-3 per week, during 5-8 weeks. Chilli was applied more than tomato because chilli takes longer than tomato to harvest. Pesticides were the primary control measure, and sometimes pesticides were combined with other controls measures such as mechanical and cultural methods. Many factors affecting the use of pesticides. These include age, education, experience, market 
price of products and alternative measures of pests and diseases (Mariyono et al., 2018a).

Table 2 shows that the effectiveness of control measures that were taken by farmers. Mostly farmers perceived that the control measures were effective or partially effective. The case of not effective occurred during the outbreak and very bad weather and farmers were late to apply pesticides, particularly fungicides. When farmers perceived that the control measures were ineffective, the causes included wrong targets, incorrect time, and inappropriate dosage of pesticides. Sometime farmers were too late to take actions. It is interesting to note that synthetic pesticides should be wisely used because such pesticides lead to health and environmental problems (Mariyono et al., 2018a).

\section{IRRIGATION-RELATED ISSUES}

Irrigation is also essential in vegetable farming (Mukherjee, Sarkar, \& Sarkar, 2018). During the dry season, the availability of water for irrigation determines the performance of vegetable farming. Table 3 shows the irrigation condition in the project areas.

TABLE 3. CONDITION OF IRRIGATION

\begin{tabular}{llrrrrr}
\hline \multirow{2}{*}{$\begin{array}{l}\text { Type and source of } \\
\text { Irrigation }\end{array}$} & \multicolumn{5}{c}{ Proportion (\%) } \\
\cline { 2 - 7 } & Water canal & 0 & 0 & 68.3 & 38.7 & 22.3 \\
\multirow{5}{*}{ Source of } & Well & 4.8 & 0 & 15.0 & 19.4 & 9.3 \\
water & Water tank & 0 & 0 & 6.7 & 4.8 & 2.4 \\
& Lake & 8.0 & 90.9 & 0 & 0 & 17.2 \\
& Rain fed & 86.4 & 9.1 & 0 & 37.1 & 46.4 \\
& drinking water & 0.8 & 0 & 5.0 & 0 & 1.4 \\
\hline \multirow{5}{*}{ Flooding } & 6.4 & 0 & 3.4 & 0 & 3.4 \\
& Flooding with & 12.8 & 0 & 69.5 & 51.6 & 45.9 \\
& bed & & & & & \\
& Manual from & 18.4 & 0 & 6.8 & 0 & 9.3 \\
Irrigation & well & & & & & \\
method & Manual from & 51.2 & 0 & 15.3 & 32.3 & 32.1 \\
& tank & 11.2 & 100 & 5.1 & 12.9 & 8.6 \\
& Pumped & 0 & 0 & 0 & 1.6 & 0.3 \\
& Drip irrigation & 0 & 0 & 0 & 1.6 & 0.3 \\
\hline & Other & & & & &
\end{tabular}

Overall, the common source of water came from rain-fed and the conventional method of irrigation flooding with the bed. Particular in Bangli, the primary source of water was a lake; and in Blitar, the primary source of water was the water canal or rivers. In Tabanan, the primary source of water was rain-fed. The difference in the source of water determines the cropping pattern in each area. Farming relying on rain-fed as the sole source of irrigation will be operated during the rainy season.

Figure 2 shows the proportion of farmers facing irrigation problem. Overall, $70 \%$ of farmers perceived that irrigation was one of limiting factors of vegetable farming. In Bangli, more 90\% farmers stated that irrigation is a severe problem. During the rainy season, there was too much water such that the land flooded by the rising water lake. During the dry season, water was available from the lake, but the cost of watering was high because irrigation needed to be carried out every day. This is because the soil type of land was sandy.

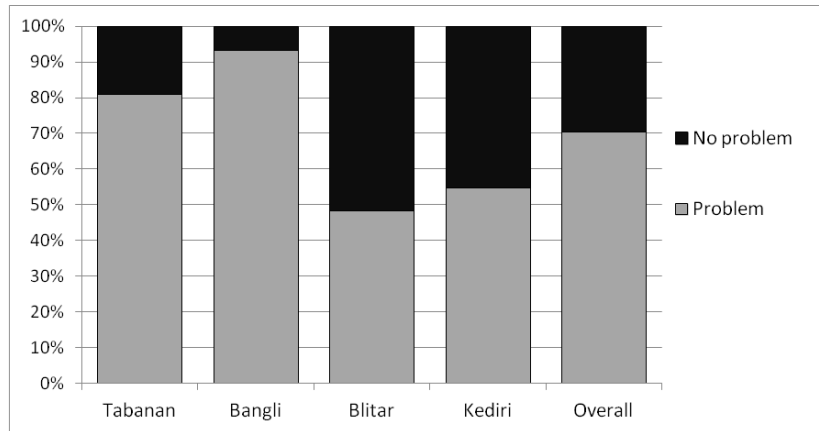

FIGURE 2. PROBLEM OF WATER IRRIGATION

Of those perceiving that irrigation was the problem in vegetable farming, categorised into several issues, which are shown in Figure 3. In general, scarce water during the dry season was perceived by farmers as the most critical issue. Another critical issue is that fact that vegetable farming was mostly situated in the sloped land, such that it was quite challenging to get adequate water. Within the area of Bangli, even though $95 \%$ of farmers stated that irrigation was one of limiting factors, they perceived that such a problem had been overcome using the water pump. They only stated that the issue of irrigation became important when fuel was scarce leading to the high price of fuel.

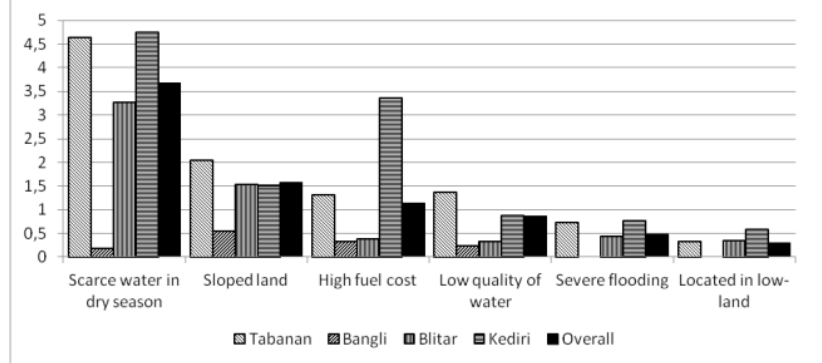

FIGURE 3. THE IMPORTANCE OF ISSUES RELATED TO IRRIGATION 
Table 4 shows the seriousness of water scarcity. Among farmers providing response, the water scarcity was not too serious. If those who did not provide response perceived that scarcity of water was not the problem. Overall, only about $10 \%$ of farmers stated that such a problem was severe. Not that, in Bangli, water is always available from the lake, so they did not provide response related to water scarcity.

TABLE 4. SERIOUSNESS OF SCARE WATER IRRIGATION

\begin{tabular}{lrrrrr}
\hline Response & \multicolumn{5}{c}{ Proportion of farmers (\%) } \\
\cline { 2 - 6 } & Tabanan & Bangli & Blitar & Kediri & Overall \\
\hline No response & 40.3 & 81.8 & 68.3 & 52.5 & 55.0 \\
Very lack & 5.6 & 2.3 & 10.0 & 8.2 & 6.6 \\
Slightly lack & 18.5 & 0 & 5.0 & 8.2 & 10.7 \\
Fair & 22.6 & 13.6 & 8.3 & 23.0 & 18.3 \\
Serious & 2.4 & 0 & 1.7 & 6.6 & 2.8 \\
Very serious & 10.5 & 2.3 & 6.7 & 1.6 & 6.6 \\
\hline
\end{tabular}

Despite such problem, farmers were able to cope with such that the problem did not stop farmers from operating vegetable farming. Farmers made efforts to cope with the problem by purchasing water from local government and use it as efficient as possible. During high water scarcity, farmers gave water to crops using a watering can together with fertiliser application.

\section{SOIL-RELATED ISSUES}

Soil condition determines the performance because it is essential ecological capital (Manea, 2017). Agricultural and will be useless if the condition is unable to support crops (Morillas et al., 2017). Figure 4 describes the main issues related to soil condition in surveyed areas. Overall, poor drainage was the main issues for vegetable farming. This is understandable because several high valued vegetables such as tomato and chilli are sensitive to water lodging. In Bali, the issue was more critical than in East Java, where poor drainage was as important as low soil fertility and low soil nutrient. More than $80 \%$ of farmers in Bali perceived that poor drainage was the important issue; contrast to that in East Java, which only accounted for about one-third.

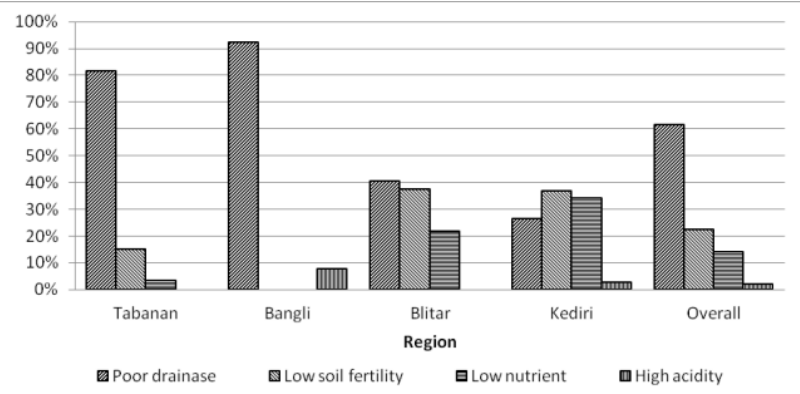

FIGURE 4. PERCENTAGE OF FARMERS PERCEIVING THE MAIN PROBLEM OF SOIL CONDITION

Figure 5 shows more detail of drainage condition in surveyed areas. Overall, drainage condition was not too bad. About $30 \%$ of farmers perceived that drainage condition was just good and fair. In Bali however, more than $80 \%$ of farmers perceived that drainage in their land was poor.

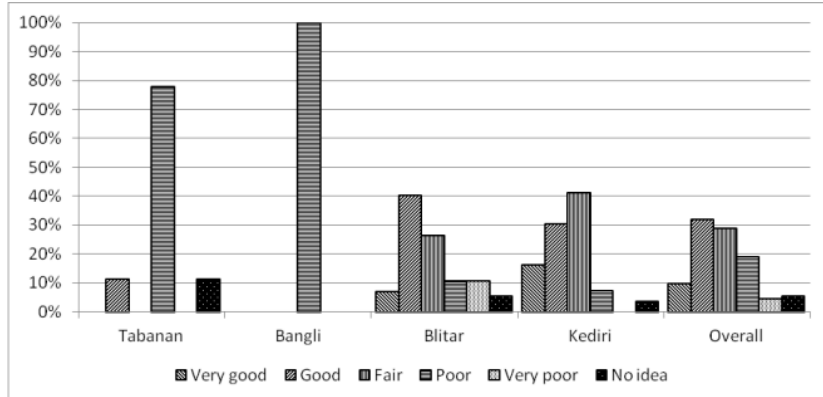

FIGURE 5. PERCENTAGE OF FARMERS PERCEIVING DRAINAGE PROBLEM

Figure 6 describes soil fertility of agricultural land in the surveyed areas. Overall, the soil fertility was not too bad, except in Tabanan. One bad situation is the fact that about $50 \%$ of farmers in Bangli had no idea about soil fertility in their owned land. Compare to those in other areas, this situation is worrying. Without knowing their soil fertility, they would just do "trial and error" in their farming. It was

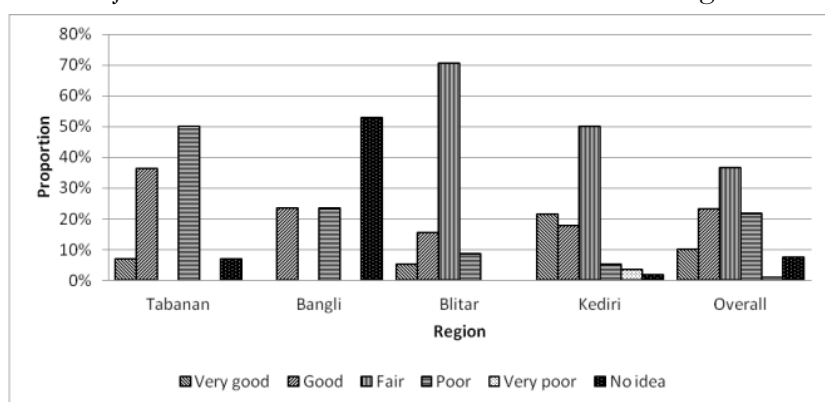

FIGURE 6. PERCENTAGE OF FARMERS PERCEIVING SOIL FERTILITY OF LAND 
suggested that farmers knew the soil fertility such that they were able to determine the right dose of fertilisers (Latifah et al., 2018).

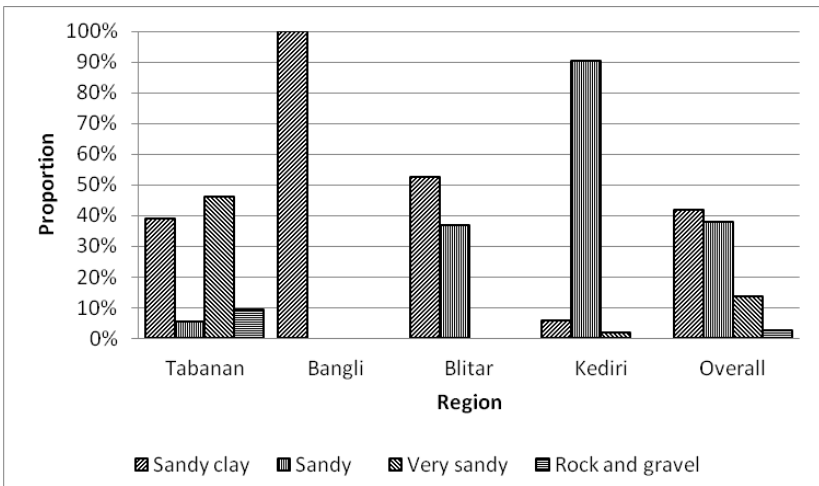

FIGURE 7. PERCENTAGE OF FARMERS WITH DIFFERENT SOIL TYPES

Drainage issue could be associated with the soil types (Wang et al., 2018). Figure 7 describes the composition of soil types. Overall, soil types in surveyed areas were sandy clay and sandy. In Bangli of Bali, where the drainage condition is the main issue was relevant to the soil type, which was sandy clay. In Blitar of East Java, the situation was quite similar to that in Bangli. In East Java, poor soil fertility and low soil nutrient were relevant to the sandy soil. Sandy soil was able to keep the soil humid, and soil nutrient is easily leached together with water.

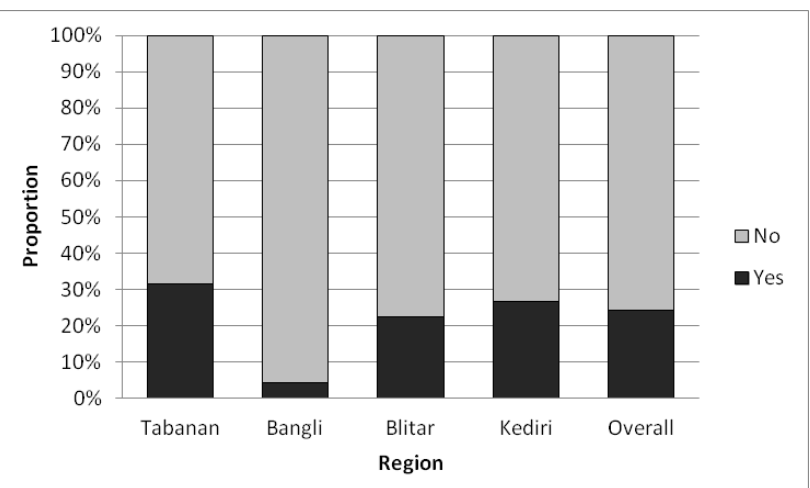

FIGURE 8. PERCENTAGE OF FARMERS KNOWING SOIL ACIDITY (PH)

One factor that determines soil fertility is the acidity of the soil. This factor is important since it affects the availability of soil nutrient to crops (Fangueiro et al., 2017). Extreme soil acidity enables essential nutrient will not be available to plants, and the condition also leads to crop intoxication. Unfortunately, more than $75 \%$ of farmers did not know the soil acidity of their land; even in Bangli, more than 95\% farmers did not know the soil acidity of their land (Figure 8). This is condition could be the root of a soil problem in Bangli.

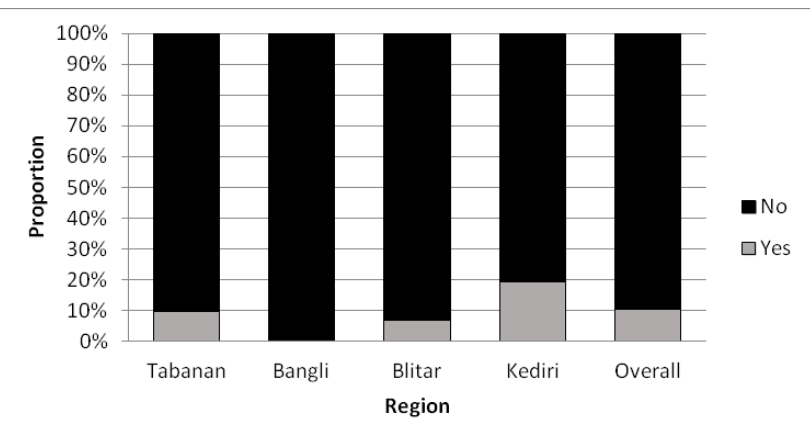

FIGURE 9. PERCENTAGE OF FARMERS HAVE CONDUCTED A SOIL TEST

Lack of knowledge on soil acidity is explainable because about $90 \%$ of farmers have not tested soil of their land in an adequate soil laboratory (Figure 9). Thus, they did have any information related to physical, chemical and biological characteristics of the soil. As the farmers lack information on soil fertility, they have not been observing the signs and symptoms of nutrient deficiency related to soil fertility.

\section{POST-HARVEST HANDLING}

A potential risk is because vegetables are perishable products, which relate to post-harvest losses. After harvest, fresh vegetables are transported from the farm to either a packing house or distribution centre. For some crops such as fruits, vegetables, and root crops, being less hardy than cereals, post-harvest losses can reach 50\% (Anonymous, 2008). Reduction in these losses would increase the amount of food available for human consumption and enhance global food security (Anonymous, 2008; Trostle, 2010).

Post-harvest handling is the last action of farming before marketing. This step is important because it determines the price of vegetable produces. Many factors affect the quality of vegetable produces. One of them is the variety of crops since each variety 
has distinctive characteristics. Table 5 shows that more than $50 \%$ of farmers in East Java giving response perceived that variety of chilli influenced the quality. There is an indication that the variety chilli in East Java was more important than that in Bali. This is understandable since chilli in East Java was marketed at a national level. Whereas, chilli in Bali was marketed only to fulfil local market in Bali.

\section{TABLE 5. EFFECT OF VARIETY ON PRODUCT QUALITY}

\begin{tabular}{|c|c|c|c|c|c|c|}
\hline \multirow[t]{2}{*}{ Crops } & & \multicolumn{5}{|c|}{ Proportion of farmers } \\
\hline & & Tabanan & Bangli & Blitar & Kediri & Overall \\
\hline \multirow{3}{*}{ Chilli } & $\begin{array}{l}\text { No } \\
\text { response }\end{array}$ & $79.4 \%$ & $65.9 \%$ & $26.7 \%$ & $12.9 \%$ & $45.0 \%$ \\
\hline & Affect & $12.7 \%$ & $25.0 \%$ & $40.0 \%$ & $48.4 \%$ & $31.9 \%$ \\
\hline & $\begin{array}{l}\text { Not } \\
\text { affect }\end{array}$ & $7.9 \%$ & $9.1 \%$ & $33.3 \%$ & $38.7 \%$ & $23.1 \%$ \\
\hline \multirow{3}{*}{ Tomato } & $\begin{array}{l}\text { No } \\
\text { response }\end{array}$ & $63.5 \%$ & $75.0 \%$ & $95.0 \%$ & $77.4 \%$ & $77.7 \%$ \\
\hline & Affect & $20.6 \%$ & $15.9 \%$ & $1.7 \%$ & $8.1 \%$ & $11.4 \%$ \\
\hline & $\begin{array}{l}\text { Not } \\
\text { affect }\end{array}$ & $15.9 \%$ & $9.1 \%$ & $3.3 \%$ & $14.5 \%$ & $10.9 \%$ \\
\hline
\end{tabular}

The case of chilli is different from that of tomato. Variety of tomato was perceived to not to have a huge influence on the quality. Market preference on tomato did not affect much by the variety. In the case of Tabanan, where farmers have particular market for tomato, the verity of tomato is more important than other regions.

\section{TABLE 6: FACTORS AFFECTING QUALITY OF CHILLI}

\begin{tabular}{lrrrrr}
\multirow{2}{*}{ Factors } & \multicolumn{5}{c}{ Rank order (the higher the better) } \\
\cline { 2 - 6 } & Tabanan & Bangli & Blitar & Kediri & Overall \\
\hline Size & 1.41 & 3.18 & 4.57 & 5.84 & 3.78 \\
Colour & 1.33 & 2.52 & 3.90 & 5.34 & 3.32 \\
Shape & 1.24 & 2.84 & 3.82 & 4.08 & 2.99 \\
Taste & 0.93 & 0.33 & 0.83 & 1.60 & 1.00 \\
Water content & 0.44 & 0.25 & 0.72 & 2.06 & 0.92 \\
Aroma & 0.51 & 0.27 & 1.27 & 1.39 & 0.90 \\
\hline
\end{tabular}

Since each variety has different special characteristics, many factors characterized the variety affect the quality of vegetable produces. Table 6 shows that size, colour and shape of chilli were the important factors affecting the quality of chilli. In East Java, farmers put more weight on these factors than those in Bali.

In the case of tomato, size, colour and shape were also important factors in affecting the quality of tomato (Table 7). However, the rank of such factors in tomato was lower than that in chilli. In contrast to East Java, farmers in Bali posited greater weight for such factors than those in East Java. One of the sensible reasons is that Bali and East Java have a different target of marketing.

\section{TABLE 7. FACTORS AFFECTING QUALITY OF TOMATO}

\begin{tabular}{lrrrrr}
\hline \multirow{2}{*}{ Factors } & \multicolumn{5}{c}{ Rank order (the higher rank the better quality) } \\
\cline { 2 - 6 } & Tabanan & Bangli & Blitar & Kediri & Overall \\
\hline Size & 2.71 & 2.27 & 0.50 & 1.53 & 1.73 \\
Colour & 2.41 & 1.82 & 0.50 & 1.05 & 1.43 \\
Shape & 2.48 & 1.93 & 0.35 & 0.97 & 1.41 \\
Taste & 1.27 & 0.32 & 0.35 & 0.23 & 0.56 \\
Water content & 0.81 & 0.18 & 0.33 & 0.29 & 0.42 \\
Aroma & 0.73 & 0.20 & 0.20 & 0.15 & 0.33 \\
\hline
\end{tabular}

There are potentials to improve and modernise the vegetable farming practices since many farmers still in traditional and subsistence stages (Mariyono et al., 2018b). The role of extension services become essential. Farming practices can be improved by sending the farmers in informal schools (Kuntariningsih \& Mariyono, 2013a), and encouraging farmers with the use of modern technology (Kuntariningsih \& Mariyono, 2014), particularly for ecological technology (Latifah et al., 2018). The training enables farmers to increase farm productivity (Luther et al., 2018) and the efficiency of resource use (Mariyono, 2018). As many factors affecting the use of modern technology (Kuntariningsih \& Mariyono, 2013b), the extension services should be updated with the current condition (Wulandari, 2015). The use of information and communication technology might be one of the best alternatives to complement the extension services because farmers could access technology and market information directly (Negoro et al., 2018). Farmers also could plan the best time to grow vegetables when 
they have access to market information (Negoro \& Mariyono, 2014).

\section{CONCLUSION}

Agroecological aspects that play important roles in vegetable production include selection of hybrid variety of vegetables, and crop protection practices. Anthracnose and late blight were perceived as the most important disease in chilli and tomato respectively. Farmers perceived that irrigation was one of limiting factors of vegetable farming. Poor drainage was one of the crucial issues in Bali. Soil fertility was not the main issues, but there was a bad situation that farmers did not know about soil fertility of their land. Farmers mostly sold vegetable once harvested. Postharvest handling was still traditional, where farmers did not pay attention to much on it. Thus, Postharvest handling still need more attention by farmers since only a small fraction of farmers were aware on that, even though they observed that high quality of produce provides price premium.

This study is expected to provide good guidance in formulating policies. From the specific condition of farming practices in each location, policies related to vegetable farming development need to be formulated wisely to cope with local specific problems. In this case, Agricultural District Services (Dinas Pertanian) in each region should formulate appropriate policies accordingly. For example, in Bali, water irrigation was perceived to be the problem, unlike in East Java. Then the local government need to solve this problem appropriately. Another instance is in East Java where product quality matters when the variety of chilli is the cause. Local government should provide more alternatives for farmers.

\section{ACKNOWLEDGEMENT}

This study is a part of the "Vegetables for Indonesia" project, funded by United States Agency for International Development (USAID)-Indonesia, led by Dr Greg Luther of the World Vegetable Center, in collaboration with Indonesian Vegetables Research Institute, Assessment Institute for Agricultural Technology East Java and Bali, Agricultural Extension Service of East Java and Bali, Udayana University and
Yayasan FIELD Indonesia. The authors thank the farmers and enumerators who provided and recorded information related to vegetable production in East Java and Bali, and acknowledge all co-principal investigators of the collaborators. Any errors in analysis and interpretation of results are the responsibility of the authors.

\section{REFERENCES}

Anonymous. (2008). Double Jeopardy: Responding to high food and fuel prices, G8 HokkaidoToyako Summit.

Bhattarai, M., \& Mariyono, J. (2016). The economic aspects of chilli production in Central Java. Economic Journal of Emerging Markets, 8(2), 85-97. Retrieved from https://doi.org/10.20885\%2Fejem.vol8.iss2.art 1

BPS. (2014). Indonesia Year Book. Jakarta. Jakarta.

BPS. (2015). Statistik Indonesia. Jakarta: Badan Pusat Statistik. Retrieved from www.bps.go.id

BPS. (2016). Indonesian Statistics of Horticulture. Jakarta: Indonesian Statistical Agency.

Fangueiro, D., Pereira, J. L. S., Macedo, S., Trindade, H., Vasconcelos, E., \& Coutinho, J. (2017). Surface application of acidified cattle slurry compared to slurry injection: Impact on $\mathrm{NH}$, $\mathrm{N2O}, \mathrm{CO} 2$ and $\mathrm{CH} 4$ emissions and crop uptake. Geoderma, 306, 160-166. https://doi.org/https://doi.org/10.1016/j.geode rma.2017.07.023

Istiyanti, E., Khasanah, U., \& Anjarwati, A. (2015). Pengembangan Usahatani Cabai Merah di Lahan Pasir Pantai Kecamatan Temon Kabupaten Kulonprogo. AGRARIS: Journal of Agribusiness and Rural Development Research, 1(1), 6-11.

Kuntariningsih, A. (2018). Impact analysis of school garden program to overcome malnutrution of children. Jurnal Kesehatan Komunitas, 4(1), 26-32.

Kuntariningsih, A., \& Mariyono, J. (2013a). Dampak pelatihan petani terhadap kinerja usahatani kedelai di Jawa Timur. Sosiohumaniora, 15(2), 139-150. Retrieved from http://jurnal.unpad.ac.id/sosiohumaniora/articl e/view/5739

Kuntariningsih, A., \& Mariyono, J. (2013b). Socioeconomic factors affecting adoption of hybrid seeds and silvery plastic mulch. Jurnal Sosial 
Ekonomi Pertanian Dan Agribisnis, 9(2), 279 308.

Kuntariningsih, A., \& Mariyono, J. (2014). Adopsi teknologi pertanian untuk pembangunan pedesaan: Sebuah kajian sosiologis. Agriekonomika, 3(2), 180-191.

Latifah, E., Andri, K. B., \& Mariyono, J. (2014). Pengenalan model kebun sayur sekolah untuk peningkatan konsumsi sayuran bagi para siswa di Kediri - Jawa Timur. Agriekonomika, 3(1), 34-44.

Latifah, E., Dewi, H. A., Daroini, P. B., Korlina, E., Hasyim, A., Andri, K. B., ... Luther, G. C. (2018). Impact of starter solution technology on the use of fertilizers in production of chili (Capsicum frutescens L.). In Paper presented at International Conference on Green Agroindustry and Bioeconomy, held in Universitas Brawijaya, on 18-20 September 2018, Malang - Indonesia. Malang, Indonesia.

Luther, G. C., Mariyono, J., Purnagunawan, R. M., Satriatna, B., \& Siyaranamual, M. (2018). Impacts of farmer field schools on productivity of vegetable farming in Indonesia. Natural Resources Forum, 42(2), 71-82. Retrieved from 8947.12144

Manea, A. I. (2017). Fertilizer type on cabbage growth and yield. International Journal of Vegetable Science, 23(6), 567-574. https://doi.org/10.1080/19315260.2017.1350 245

Mariyono, J., Daroini, P. B., Dewi, H. A., Latifah, E., Zakaria, A. Z., \& Afari-Sefa, V. (2018). Marketing aspects of vegetables: Comparative study of four regions in East Java and Bali. Agriekonomika, 7(1), 46-56.

Mariyono, J., Dewi, H. A., Daroini, P. B., Latifah, E., Zakaria, A. Z., \& Afari-Sefa, V. (2018). Marketing aspects of vegetables: Comparative study of four regions in East Java and Bali. Agriekonomika, 7(1), 46-56.

Mariyono, J., Dibiyantoro, A., \& Bhattarai, M. (2010). Improved technologies in vegetable production to support food safety and food security: A case of chili farming in Central Java. In International Conference on Food Safety and Food Security. Yogyakarta: Universitas Gadjah Mada, Yogyakarta, Indonesia.

Mariyono, J., Kuntariningsih, A., \& Kompas, T. (2018). Pesticide use in Indonesian vegetable farming and its determinants. Management of
Environmental Quality: An International Journal, 29(2), 305-323. https://doi.org/10.1108/MEQ-12-2016-0088

Mariyono, J., Kuntariningsih, A., Suswati, E., \& Kompas, T. (2018). Quantity and monetary value of agrochemical pollution from intensive farming in Indonesia. Management of Environmental Quality: An International Journal, 29(4), 759-779. https://doi.org/10.1108/MEQ-03-2017-0030

Morillas, L., Roales, J., Portillo-Estrada, M., \& Gallardo, A. (2017). Wetting-drying cycles influence on soil respiration in two Mediterranean ecosystems. European Journal of Soil Biology, 82, 10-16. https://doi.org/https://doi.org/10.1016/j.ejsobi. 2017.07.002

Mukherjee, A., Sarkar, S., \& Sarkar, A. (2018). Productivity and profitability of tomato due to irrigation frequency and mulch. International Journal of Vegetable Science, 24(1), 43-57. https://doi.org/10.1080/19315260.2017.1378 786

Negoro, A. A., Kuntariningsih, A., Dewi, H. A., Daroini, P. B., Latifah, E., Zambani, M. A., \& Setyoko, $\mathrm{H}$. (2018). The usage of information and communication technology in improving biobusiness performance: a case of vegetable farming in Indonesia. In Paper presented at International Conference on Green Agroindustry and Bioeconomy, held in Universitas Brawijaya, on 18-20 September 2018, Malang - Indonesia. Malang, Indonesia.

Negoro, A. A., \& Mariyono, J. (2014). Peran sistem informasi dan teknologi luar musim dalam bisnis berbasis komoditas sayuran. In Prosiding Seminar Nasional PERHORTI 2014. Malang: PERHORTI.

Paramanandham, P., Rajkumari, J., Pattnaik, S., \& Busi, S. (2017). Biocontrol potential against Fusarium oxysporum f. sp. lycopersici and Alternaria solani and tomato plant growth due to Plant Growth-Promoting Rhizobacteria. International Journal of Vegetable Science, 23(4), 294-303.

Sita, B. R., \& Hadi, S. (2016). Produktivitas dan faktorfaktor yang berpengaruh terhadap produksi usahatani tomat (Solanum lycopersicum Mill) di Kabupaten Jember. Jurnal Sosial Ekonomi Pertanian, 9(3), 67-78.

Trostle, R. (2010). Global Agricultural Supply and Demand: Factors Contributing to the Recent 
Increase in Food Commodity Prices (No. WRS0801).

Wang, R., Sun, Q., Wang, Y., Zheng, W., Yao, L., Hu, Y., \& Guo, S. (2018). Contrasting responses of soil respiration and temperature sensitivity to land use types: Cropland vs. apple orchard on the Chinese Loess Plateau. Science of The Total Environment, 621, 425-433. https://doi.org/https://doi.org/10.1016/j.scitote nv.2017.11.290

Weinberger, K., \& Lumpkin, T. A. (2007). Diversification into horticulture and poverty reduction: $A$ research agenda. World Development, 35(8), 1464-1480.

White, B., Morey, P., Natawidjaja, R., \& Morgan, W. (2007). Vegetable value chains in Eastern Indonesia-a focus on chilli.

Widodo, A. S. (2015). Pendapatan dan Produksi Potensial Usahatani Konservasi Lahan Pantai di Kabupaten Bantul. AGRARIS: Journal of Agribusiness and Rural Development Research, 1(1), 1-5.

Wulandari, R. (2015). Information Needs and Source Information of Agricultural Extension Workers in DIY. AGRARIS: Journal of Agribusiness and Rural Development Research, 1(2), 85-97. 